\title{
THE DOCTRINE OF THE GODS IN NUMENIUS' ONTOLOGY
}

\begin{abstract}
The paper analyses the positions of Numenius on the status of the two, or rather the three gods, in his ontological system. In relation to his doctrine of the three gods, the problem of his theoretical inclination towards the East, especially Judaism, is briefly mentioned. The main points from the ontological background of the positioning and the characteristics are offered - the opposition between God and Matter, the assumed hierarchization of the divinity according to the various functions, and the status of the demiurgic principle. Hence, the relation between the First God and the Second God, and the possible division of the First, or, much more likely, the Second God into two gods are shown through the suitable examples from the extant fragments of Numenius' works.

The distinction between the First God, simple, solitudinous and focused only on himself, and God who is divided into a Second and Third God, that is, the cosmos as a product of the Second God, is displayed. The ideas on the division of God by Matter are briefly expressed, as well as the ideas about the equivalence between the Supreme (First) God with the Good, and the way the Demiurge receives goodness. The claims according to which the First God, the principle of existence, governs the (sphere of the) being, and the Second God - the realm of becoming are listed. The reasons for the complexity of the theological concept of Numenius are glanced at, as well as the ways in which the confusion could be overcome.
\end{abstract}

Keywords: NUMENIUS, FIRST (SECOND, THIRD) GOD, DEMIURGE, MATTER, BEING

Numenius (of Apamea), a representative of the Middle Platonism, or Neopythagoreanism, ${ }^{1}$ analyses various religious beliefs through the prism of Plato's philosophy. In this text, the theological doctrine of Numenius, that is, his ontological-theological concept of the three gods ${ }^{2}$ will be briefly explored. Although it is a concept most characteristic of Numenius, he originally ascribes it to Socrates. According to Numenius, Socrates posited three gods, and narrat-

\footnotetext{
${ }^{1}$ There are also indications of his connection with the Chaldean prophesies and the Hermetic tradition (Dillon 1996, 94ff; Dodds 1960, 10; Hillar 2012, 183).

2 The use of a capital first letter for "God", "Demiurge", "First God", "Second God", "Third God", and the other key theological categories varies in Numenius, which is why it is inconsistent in this text as well. The citations go along the principle (work, book, fragment/the fragment in the edition Numénius, Des Places 1973).
} 
ed about them in a style suitable for each of them separately. Those who listened to him did not understand what he was doing, and thought that he was being inconsistent, that he spoke in disorder and with no plan. Plato, who followed Pythagoras, knew that Socrates had taken these stances exactly from him. He would connect his topics in a way that was not conventional, nor clear, treating each god exactly as he deemed he should, obfuscating his positions between clarity and obscurity. In such a way, he provoked certain reasons for disagreement and for the subsequent twisting of his words, which was not due to envy or malice, but simply, to a lack of understanding.

For Numenius (and this is important regarding his placement in the philosophical tradition), Plato is a Neopythegorean, as is Socrates. Socrates and Pythagoras are equivalent in their status, and Plato presents their middle ground, for he has diminished the solemnity of Pythagoras to render him more humane, and elevated the cunningness and playfulness of Socrates from the level of irony to that of dignity and gravitas. Plato is a mixture of Pythagoras and Socrates, demonstrating himself to be more accessible than the former and more dignified than the latter (On the Dissension of the Academics towards Plato, Fr. 24/1 L).

The question concerning the source from which Numenius had discovered this Socratic concept arises. The positions on the three gods, along with Plato's claim that of some things (and things of crucial importance, no less) he had never written anything, and that there is no extant discourse (text) by Plato, but rather that those who bear his name belong to Socrates, are contained in Plato's Second Letter (Ep., II, 314c). Merlan thinks that Numenius incorrectly assumed that it was a new paragraph, and that this "belong to Socrates" refers to the entire previous part of the letter, which makes the doctrine of the three gods a doctrine by Socrates (Merlan 1967, 97). Numenius' concepts, assuming they were inspired by Plato, contribute to the legitimization of the proposed system from Plato's unwritten doctrine of the Tübingen school. However, this problem has not been extensively researched, and, in any case, merits a separate approach.

The problem of the original doctrine of the three gods in Numenius is related to two further problems: his preference for the religious concepts of an incorporeal deity, and his sympathies towards the eastern teachings, especially the connection with Judaism. Numenius announces that, in order to establish his position and form his conclusions, he will retire to the legacy of Plato, and connect it to the words of Pythagoras. Therefore, he refers to those who had been admired by Plato, borrowing from their rituals and consecrations, or rather, from whatever it was that Brahmans and Jews and mages and Egyptians organized (On the good, I, 1a, or rather $9 \mathrm{aL}) .^{3}$

${ }^{3}$ Numenius includes the Jews in the catalogue of all the peoples who considered God to be incorporeal, not hesitating to quote the words of the prophets in his works, or to give (plausible) allegorical interpretations $(1 \mathrm{~b} / 9 \mathrm{bL})$. The belief in an incorporeal god can be 
Merlan does not think that the various references to the Jews, and especially Moses, confirm an intense orientalising or Judaizing tendency. He sees no proof in Numenius that he ever considered the "barbaric", or in particular, the Jewish wisdom, to be superior in relation to that of Plato's, or as Plato's source or inspiration. The attitude Numenius had for the East is best compared to that of Plutarch, who liked to refer to Persian and Egyptian concepts, or to that of Dioegenes Laertius, Merlan claims (Merlan 1967, 99). Merlan includes in this Numenius' theory on the two cosmic souls (of which the latter might be identical to the second god), and, as a rather "non-Greek" theory, that of the two souls within man (36L). The famous position of Numenius, that Plato was a Greek-talking Socrates, remains problematic in this evaluation, a fact of which Merlan is completely aware, despite his claims about the lack of confirmation about Numenius' inclination towards the Jewish intellectual tradition. ${ }^{4}$

The First god, by staying in his own place, is simple, and by being together with himself, can never be divided. The Second, or the Third god, however, is one (IV or V, 11/20 L). He comes into contact with matter, which is dyadic and, although he unifies it, he is divided by it, since it has an appetitive and fluid character (Ibid.). Gazing on matter, he is not intent on the intelligible (for in that case he would have been intent on himself); by directing his entire attention to matter, he becomes unmindful of himself. Having gotten to grips with the perceptible and having been absorbed in his work with it, by devoting himself to matter he chooses it and elevates it even to his own character. In fr. 11 the cosmos is represented as God, which makes the unity of the Second and the Third somewhat unclear. It can be assumed that Numenius does not think that the cosmos is a god in the same sense that the First and the Second Principle are gods, but rather that it has a divine nature, as a creation of God, full of divine presence.

The Second god is a principle that in a way serves as a mediator between completely opposed principles (God and Matter). The force that introduces order into Matter must originate in the highest of Gods, for he is the principle of order and goodness. And yet, it has to be separate, so that it can be possible that God remain static and undisturbed by Matter, which endangers the absolute divine unity. This would mean that God is simultaneously unified and divided. ${ }^{5}$

pointed out as the reason for his obvious respect for the groups (the peoples) he enumerates (Fr. 18/19 L).

${ }^{4}$ According to Merlan, regarding the question about which aspect of Plato's philosophy Numenius had envisaged, in order to compare him to Moses, a fair guess would be that it was the way Plato, in connection to the introduction of the artificer, used the terms to on aei on the one hand, and the Biblical construction "I am he who is/am" on the other (Merlan 1967, 100).

${ }^{5}$ Lansegth finds interesting Numenius' intention to make distinctions in respect of the First and the Second God, through the use of diairesis, a philosophical tool used by Plato (especially in Statesman and Sophist). Diairesis serves to define a certain topic more 
From the necessity for the First (god) to create, depends the determination of the status of the Demiurge - thus, if it is not necessary for the First to create (IV or V, 12/21 L), then the First God should be considered a father to the Demiurge. ${ }^{6}$ However, Numenius wants to focus his research. If the discussion is about the "demiurgic principle" and if we announce that that which preexists should be able to directly create, then, this would be the argument. Nevertheless, if it is not about the Demiurge (the creator), if the research is about who the First was, such language would be impious, Numenius thinks.

First we have to unambiguously agree that The First (God) is not employed in any way (remains inactive in the creation), insists Numenius, and that He is King. The Demiurge (God) is in charge, he circles the heavens and rules upon. Our life journey unfolds due to him, when the Mind directs itself downwards, through the spheres, towards all of those destined to participate in it. The idea is that as long as the god looks at us, turns to us, our bodies are alive, animated by the divine radiance with which they unite.

If, however, the God returns to his vantage place of self-surveying, everything gets extinguished, except for the Mind, who continues with his life, rejoicing in his own blessed existence (IV or V, 12/21 L). The relation of the First God to the creator (the Demiurge), is like that of the farmer (or farm-owner) to the one who does the planting.7 The one who is the seed of every soul connects all things together into things which have a share in him; but the lawgiver plants and dispenses and alocates within each of us that which had been previously prepared by the First God (IV or V, 13/22 L). The difference between the First and the Second God, illustrated through the agricultural simile, is in that the First God is like the farmer, he sows the seed of every soul in its suitable receptacle, while the Second God is like the one who takes care of the seeds, plucks them out, and transplants them into individual people.

Dodds claims that this must have been based on Timaeus 41c-d, except that the function of the Demiurge of Plato's is here confusedly transferred to the First God, and the function of the lesser gods, to the Second God. A part of the obscurity is due to the destroyed translation - it turns out that Numenius says

precisely, by disqualifying the irrelevant members of a larger group (Langseth 2013, 102-103). Numenius plans on somehow using this method in order to define the First and the Second God, whom he assumes real. The definition he arrives at is that of the different levels of the deity: the determining factor of each god is his relation to matter. Thus, Langseth formulates that when “... the philosopher makes his distinctions in the second half of this fragment, the distinctions that appear become spheres of activity, and the last lines sound like divine drama" (Langseth 2013, 105).

${ }^{6}$ The English translation by Boyce-Stones reads "in fact, what is first (the first principle, or the first god) should not create either. Indeed, the first god must be considered the father of the creator God" (Numenius, Boys-Stones 2014, 6).

${ }^{7}$ Des Places remarks that the difference between the farmer and the planter was envisaged as the relationship between the owner of the land, and the worker who works said land (Des Places, ad fr. 9). 
that the First God is the seed of the soul which plants it, which is incorrect (Dodds 1960, 15). ${ }^{8}$ In the extant parts from the Numenian opus, there is nothing to suggest that the First (god) should denote both Being and Primarity. As one of the conclusions in the debate about the proposed ways to understand the First principle by Dodds, Whittaker suggests that if no suitable justification for this proposal by Dodds is found, then there is no reason to even include "the first" in fr. 13 (Whittaker 1978, 150). Whittaker, following Festugière, thinks that Numenius had in mind the part from Ex. 3,14, and locates Philo as the most logical connection between the Old Testament source and Numenius (Whittaker 1967, 196). Tarrant thinks that Whittaker is indubitably right when he assumes that Numenius was acquainted with the Judeo-Christian way of referring to God as "he who is", especially since other philosophers in his time period, less concerned with the Greek religion, had teachings which encompasssed similar formulae. As far as the proposed revision of the translation of fr. 13, Tarrant does not claim that it would not be needed, but sees a much bigger problem in the reconciliation of this fragment in relation to Timaeus 41a (Tarrant 1983, 19-20). ${ }^{9}$

The First God is fixed, unmoving, while the second is in motion. The First applies himself to intelligible object, and the Second, to both intelligible and sensible objects, Numenius claims. The motion belongs to the Second god, and the natural motion of the First god is stillness. From him, order proliferates through the universe, as well as his permanence, stability, and safety (IV or V, 15/25 L).

This means that in the divine hierarchy by Numenius there is a distinction between the First god, simple and focused solely to himself, and a god that is Second and Third. The Second and Third are one god, but they can also be seen as separate. The point is that when God is connected to matter, he is divided by it. The Demiurge is not the Gnostic unknowing Demiurge, but more like the Demiurge in Timaeus, although the distinction between a supreme god and a creator god is a Gnostic idea. ${ }^{10}$ The god of Timaeus does not mind his per-

\footnotetext{
${ }^{8}$ Regarding whether "the First" refers to First Being/First God, and in the light of Whittaker's attack of the proposed solution for the translation and interpretation of fr. 13 by Dodds, see Whittaker 1967, 196, and Whittaker 1978, 144-154.

9 There is no problem in the fact the Numenius calls the First God "he who is", at least not more than the fact that he calls the Second God "law giver", but Tarrant thinks that the question is more about the reason why Numenius would chose these description in the context of fr. 13, especially since they do not elucidate the proposed analogy (Tarrant 1983, 23).

${ }^{10}$ Dillon anticipates a problem in Numenius' stance that the demiurge creates as a result of orexis for matter (a desire, an appetite, a longing), using the word lust (Dillon 1996, 369). Des Places uses desire, désir. Carabine thinks that desire (in the sense of striving for something) is closer to the meaning by Numenius (Carabine 1995, 96). Precisely because in Gnosticism it is believed that the demiurge creates without knowing about the forms, De Vogel suggests that the Second God in Numenius should not be equated with the Gnostic demiurgic concept (De Vogel 1964, 25). Besides, there is the option that the source of this idea in Numenius is not Gnosticism, but Philo (Leg., III, 207).
} 
fection, on the contrary, he wants to share it, and to install order into chaos, which is perfectly within his nature. The system in Numenius does not allow for this to be the final solution. The demiurge described in Timaeus is not defined as motionless and static in the same way as being in Numenius.

If the Demiurge (the creator of the becoming) is good, the Demiurge in relation to essence will be the Good itself, with the same nature as the essence. The Second (god), by being dual, is personally responsible for the production of the Form itself, and the world - on the one hand he is the creator, and on another hand he is completely dedicated to contemplation. Numenius then numbers the four entities: the First god, the Good itself; the one who "imitates" it, the creator (the Demiurge), who is good; the substance (ousia, essence), one being from the First (god) and one from the Second (god); and its copy, the beautiful cosmos, beautified by its participation in the Beautiful (On the Good, $\mathrm{V}, 16 / 25 \mathrm{~L})$.

Numenius explains how Plato figured out that only the Demiurge was acknowledged by the people, while the first Mind, Being itself, remained completely unrecognized. Therefore, as if Plato had wanted to say that the Mind for which people think that is first actually is not, but instead there is another Mind that precedes it, ancient and divine, Numenius expounds.

Numenius illustrates the ontological construction in the following fashion. A navigator in the middle of the sea sits high up, above the rudders, and steers the ship, Numenius writes, but his eyes and mind are intent on the sky, towards the heavens, and, as far as he is concerned, his path follows the direction from the heavens above him, although he sails through the sea bellow him. Having tied up matter together in harmony, so that it cannot fall out or slip away, the Demiurge sits above it, like the ship at sea. He directs the harmony and, instead towards the heavens, looks at God above him, who attracts his gaze. From this contemplation he receives his faculty of judgement and the faculty of impulse - from his yearning (VI, 18/27 L). Numenius explains that we understand bodies through an induction from bodies similar to them, as well as from the distinct signs shared by things that are in juxtaposition. The point here is that there is no way to understand the Good from something that is juxtaposed to it, or from some perceptible thing that is similar to it, but rather a different approach is needed. We must back away, far from the objects, so that the perception can unite with the Good, who is alone, and which is an ineffable, completely inexplicable divine solitude (I, 2/11 L).

Referring to the idea of the superiority of the Father over the being and the mind, Dillon points to his own conclusion from his work The Middle Platonists, and remarks that Numenius hesitated about the idea, led by the positioning of the Second god who was to be equated to the True being and the

Concerning the possibility to understand the distinction between the Second and the Third god as a distinction between the transcendent and the immanent aspects of the demiurge, see Puech 1934, 756. 
Mind, but never actually dared to claim this. Dillon thinks that the traditional connection in the Greek philosophical tradition of the concept of God who is in a complete sense both Being and Mind is difficult to fade away. Despite Numenius' openness to the influences of the Eastern religions, it seems that he was not ready to abandon this concept. Still, Numenius came close to abandoning it, Dillon claims. Therefore, when Numenius offers the image of glancing to, or gazing at, the Good, like watching a boat leap onto the waves, he explains its sphere as an absolute and inexplicable solitude, and the Good as something that stands on Being.

This formulation carefully balances between the idea that something is superior to, or above Being, and the highest level of Being (Dillon 2007, 398). It can be asserted that for Numenius, the Good is in some way beyond Being. On the other hand, Dillon continues, the fragment ends with the formulation of the supreme object of our quest - the existence ti esti to on, which confirms that $\mathrm{Nu}$ menius has not positioned the Good as superior and beyond Being (Ibid.).

The things that participate in the Good do not participate in anything else, except for the thought. In this (and none other) way, the advantage of being united with it can be achieved. As far as the thought goes, it is only with the First (god). Plato has shown through a syllogism that the Good is one, Numenius explains. This is because if the Second (god) is good, not because of himself, but through derivation from the First, obviously that in which it participates in order to be good is itself good, ${ }^{11}$ especially since the Second participates in it as the good $(19 / 28 \mathrm{~L})$.

Writing about the Demiurge in a prosaic and vernacular fashion in Timaeus, Plato determined that "he was good" (29e), and he called the Good in Republic "the Form of the Good" (508e), Numenius mentions. So, the good is a form of the creator, who appears as good to us, participating in the first and only [good]. Therefore, Numenius claims that if the creator is good by virtue of his participation in the First Good, then the first Mind (Intellect), as the good itself, would be his Form (20/29 L).

Numenius calls the First God father, the Second creator, and the Third God an artifact, for it is the cosmos. According to him, the creator is double, the First god and the Second god, while that which is created is the Third, which means that this relation follows the scheme of ancestor - offspring (son) - descendent (grandson). ${ }^{12}$ Proclus (according to whom we have this fragment),

${ }^{11}$ This could be seen as a double meaning: it is itself good, and at the same time the Good itself.

12 There is an obvious inspiration from the Hermetic Corpus, or possibly from some common source: on One Source all things depend, while the Source depends on the One and only on the One. The Source is moved to become a Source again, while the One is forever in stillness and unmoved $(\mathrm{CH}, \mathrm{X}, 14)$. They are three: God, the Father and the Good; the cosmos; and the man. God contains the cosmos, and the cosmos contains the man. The cosmos is always a Son of God, and the man is like a child of the Cosmos (ibid.). See also: $\mathrm{CH}$, VIII, 1; VIII, 2; VIII, 5. 
claims that Numenius is wrong in including the Good in these causes, for it should not be connected to other things, nor should it be secondary in relation to anything $(21 / 24 \mathrm{~L}){ }^{13}$

This is the account on the doctrine of Numenius by Proclus, in the Commentary of Timaeus, and could be seen as an exaggerated simplification. According to Proclus, Numenius envisages three gods, calling the first Father, the second Creator and the third Created (poiema), for the cosmos is according to him the third god. Along this theory, the creator (demiourgos) is double - constituted by the First God and the Second, while the third god is the creation (to dedemiourgemenon). Proclus prefers these appellations, instead of "using his pompous terminology - grandfather, son and grandson" (21/24 L). Dillon sees no reason to doubt that Numenius really did use this terminology, but suggests that Proclus is wrong about two points in this summary. From the fragments it is understood that the "creator" is/are not the First and the Second god, but rather the Second and the Third god, and in the same line, the Third god should not be separated from the Second, but should rather be seen as his inferior aspect. Proclus was partially in the right in his interpretation of Numenius: there is a certain degree of interaction between the three gods in Numenius (Dillon 2007, 400). ${ }^{14}$ It appears the Proclus doubles the wrong god - he claims that the Demiurge is the First and the Second god together, although Numenius himself claims that the Demiurge is the Second god (fr. 12, for example), by which he means the Second and the Third God together (the two gods who are one). ${ }^{15}$

Regarding the first principles, Numenius rejects the Stoic theory in favor of the doctrine by Pythagoras, with which, as he remarks, Plato concurred. Pythagoras called god "singularity" (a monad), and matter, "duality" (a dyad), and claimed that the indefinite duality is not generated, but that the limited duality is generated. The idea is that the duality has no origin or creation be-

${ }^{13}$ In fr. 16 Numenius explains that the first God is called nous, he is the Good itself and the principle of existence, or that he is the Demiurge of being, according to which the Second god is the principle of becoming. In fr. 21, it reads that the First and the Second (god) is double, not the Second and the Third. In fr. 22 the idea of a close connection between the First and the Second god is reiterated. Thus, the First is the one which truly is, connected to the Second god through nous, and to the Third, through discursive thinking. Proclus founds this connection between the First and the Second god on Numenius' stance that the First god is the Demiurge of Being.

14 The understanding of the concept of the three gods has been further complicated by Proclus' description of the three gods (fr. 21), in which, according to Proclus, Numenius used "the father and the creator" from Timaeus like he was referring to two separate gods, although in the words of Timaeus it is clearly the same demiurge (Dillon 1971, 143-144).

${ }^{15}$ See this point in Merlan 1962, 140; Dillon 1996, 367.

Dörrie understands that Proclus is wrong, but for his mistake he blames Numenius' insufficiently strict distinction between the highest principle and the material world (Dörrie 1970, 222). This is also wrong, however, considering that in books I-III from On the Good there is exactly that type of distinction. 
fore it is adorned and beautified by god, the agent of order. The creation happens late, which is why the disordered and uncreated duality should be thought of as coetaneous with god, who brought it into order. However, some Pythagoreans did not understand this claim correctly, and thought that Pythagoras meant that the indefinite and unmeasured duality proceeded from the singularity, which merely disguised itself as duality, regressing its nature. This is not true, because the singularity, according to him, ceases to be what it was, and sub-exists as something it is not, as duality (this applies to the transformation of god into matter, and of singularity into a broad, indefinite duality), and no one with a modicum of education should accept it, Numenius claims.

Furthermore, he reminds us that the Stoics thought that matter was finite and limited by its own nature, and Pythagoras - that it was indefinite and limitless. The Stoics argued that something whose nature is to be immeasurable cannot be confined within limits, or set into order. Pythagoras, though, claims that one thing does indeed have both the capability and the power to do so, and that is god. That which nature cannot achieve, god easily can, for he is more powerful than any ability, that is, he is himself the source of all of nature's abilities (52/30 L, CCXCV).

Pythagoras thinks that matter is in flux and devoid of qualities, although not in the Stoic sense of an intermediate position between good and evil, because according to him it is quite obviously harmful, Numenius summarizes. Pythagoras (like Plato), claims that god is the principle and reason for anything that is good, and matter - for that which is evil. The product of form and matter is indifferent (like the mediatory nature of the Stoics), and that is not matter, but the cosmos as a mixture of the goodness of the form and the evil of matter. Because of this, Numenius ponders, the old theologians thought that the world was born out of providence and necessity (52/30 L, CCXCVI).

Numenius explains that according to Plato, the good things have been assigned to the world by a fatherly god, and the bad things cling to it through the evil of nature. If god has fixed matter, which is characterized by impatience, impulsivity and such, and has established order into its chaotic exited presumption (like it reads in Timaeus), then it has to be assumed that its confused intemperance stems from some hazardous chance, and not from the protective plans of providence. The soul of the matter is not without substance, Pythagoras thinks, but it opposes the providence, trying to defy its plans through the forces of its wickedness (Тодоровска 2018, 193).

According to Numenius, only the Demiurge is knowable, while the First god (the first nous, the Beauty in itself), is completely unknowable. It is possible that Numenius speaks in Gnostic terms, but it is more likely that he refers to Plato, having understood him in the sense that there exists a father, and there exists a creator, wherefrom he establishes his position on the unknowability. The Mind (nous), which the human intellect (barely) perceives is not the First god, because another mind exists before him, even more divinely. This leads to the idea that God is about nous, which, together with the reference to 
the First god as nous, introduces further confusion regarding the status of the divine hierarchy, especially since in fr. 16 the First god is not represented as a thinking mind, because in order for him to think, he needs the Second god. The First god remains on the level of being and nous.

The supreme god is the "form of the Good" (from Republic 508E), keeping in mind that the First god is the form from which the Demiurge receives its goodness. Despite several pointers that suggest that perhaps Numenius' intention was to introduce a transcendent principle (in the sense that it is beyond existence and beyond the mind), there are no extant fragments containing attempts at an explicit formulation of this concept.

The supreme god, who is eternally present, can also be considered as the Good (or Goodness; tagathon), first intelligence, incorporeality, The one who is, or Being. The First god can be seen as a Form in a Platonic sense, and also to serve as a paradigm for the Second god, who can be seen as second intelligence or creator, and who is good because he participates in goodness. Furthermore, as it was mentioned, a Third god could be assumed - the world as a product of the Second god. Also, the Second god can be considered to be double - partially dedicated to contemplation of the First god (or the intelligible), partially dedicated to creation, and, according to the Forms as guides, to the maintenance of the visible cosmos. In this final function he is in danger of dedicating too much attention to matter, from which he creates the cosmos.

The First god has no need to do anything, has no work - according to this the cosmos is not his work, but a work by the Second god, the creator. The First god governs over the sphere of being, he is the principle of existence, and the Second god rules the becoming. The First god is a principle of unification, opposed to Matter (or the dyad). God is static and undivided ("the Good is one", fr. 19). He is that which is, the being (in book II represented as noetic).

The Second God does his noetic actions between the First and the Third God. The Second God is a principle that is noetic, but divided, constituted by several noetic objects. He contains the Forms, which makes it something of a divine Mind. ${ }^{16}$ The Third God, the result of the Second God's forgetting of himself and his intense caring about Matter, is the active principle. He organizes Matter according to the noetic models provided by the Second God. According to O'Brien, an equivalence between the being and the First god can be made, following fr. 17. This, however, is not indisputable, for it seems that Numenius struggles with the idea that his First god is beyond being (it rides upon Being, fr. 2). O'Brian claims that Numenius is almost forced into this position, because his Second God

\footnotetext{
16 See the positions in Rist 1962, 179; Dillon 1992, 100; Langseth 2013, 108-109. According to Hillar, in the Pythagorean-platonist religious tradition, Numenius has introduced the Second transcendental (sic!) and noetic entity between the supreme being and the universe. Indubitably under the influence of Plato's statement about the three principles, he derived the concept of the Three Gods, distinguishing all things by their status and order (Hillar 2012, 183-186).
} 
is equated with true being and intellect, and yet does not divert from the traditional Greek identification of God with the Being and the Mind (O'Brien 2015, 142).

The Third god creates by applying on Matter a unifying action, thus resembling the Demiurge from Timaeus. Plato's Demiurge creates by looking at the Forms, who, in Numenius' system, are thoughts in the mind of the Second god. This interpretation of the identity of the three gods Frede deems controversial (Frede 1987, 1054-1055). Still, the fact that Numenius talks about two gods, or rather three gods, can easily be resolved by his stance from fr. 11, that the Second and the Third god are one. There is no understanding in Frede (Frede 1987, 1056-1058) that the Second God is ether the divine Mind (the second of three gods), or the two gods that are one (the second of two gods).

Carabine does not think that Numenius saw the First god as the demiurge of the world, but simply as the source of existence. She finds fault in the incompatibility of the understanding of god as a demiurge with the other fragments, which would be avoided when the formulation would read "a principle of being/existence" (Carabine 1995, 98). By organizing Matter, and creating with it, the Third God creates ontological layers between himself and Matter. ${ }^{17}$

The triadic division of the divinity in Numenius simultaneously is and is not complex. Hence, it can simply be understood that these are the Three Gods, who proceed from (the discussion of) the Two Gods, due to the fact that the contact with Matter divides the Second God into two functions, who are then considered as separate deities. On the other hand, the difficulty consists in the account of the Second and the Third God as sometimes separate, and sometimes different functions of the same (the Second) God. There are some formulations in which the Second god is not divided in Second and Third god, and instead is one God who thinks and acts. Another problem is that the "amalgamic" Second god has a creational aspect (which, incidentally, gets from the Third), and also because Numenius presents it as Demiurge (fr. 12 and 16, for example), although the demiurgic function is more precisely filled by the Third God, the creator. Still, from the context it can be gathered of which God Numenius is talking in the instances where he refers to the "Second" god..$^{18}$

The Second God (the two gods who are one) is constituted in that way, due to its contact with Matter. The supreme God remains completely untouched by any kind of influence of Matter, in his own area, while the lower god is

\footnotetext{
${ }_{17}$ Martano's summary refers to the statement by Proclus that the Third god is the cosmos, which is not true in the light of fr. 11 - the Third God touches the sensible sphere and elevates it to his own character - he creates the world (Martano 1960, 40). Therefore, he lists the levels of the metaphysical/theological scheme of Numenius, enumerating them as 1. the Good, 3. the Demiurge who thinks and acts, 3. the World, 4. the non-existent (Matter, Ibid., 47) - also here the Third God is equivalent to the world, and not the Demiurge who creates.

${ }^{18}$ Langseth suggests a difference in the use of the determined article - he refers to the Second of the Three Gods as the "Second God", the divine Mind, and to the Second of the two Gods as "The Second God", Langseth 2013, 109.
} 
produced through the experience of the division by Matter in two ways through the separation from the First God, and an internal split into the Second God (the divine mind) and the Third god (the creator).

In a handy table in which he compares the basic ontological-theological categories in st. Justin Martyr with the concepts in Numenius, Hillar summaryses the following. The First God is the father to the Second God, simple and indivisible, the Good (in itself), the source and principle of being, immutable. He does not create directly, is dedicated to the intelligible, he is in a final analysis of the cause of everything. From him stem the order and eternity of the world. With the Second God he is connected like the farmer is with the one planting the seed; he is connected to everything that is alive as its principle. The Second God acts as the creator, the Demiurge, he is dedicated to both the intelligible and the sensible sphere. He creates by virtue of his desire for the Third God. When he is intent upon us, the bodies are animated by his radiance. The Second God is a law-giver; he replants and transplants that which has been planted into him by the First God. The Second God is good by virtue of the participation in the Good by the First God. The Second God is an image and an imitation of the First. The Third as a world is produced by the Second, and as mind is connected to the human discursive thinking. The relation between the First and the Second is like that of a fire kindled by another fire, like farmer and planter, donor and recipient. The relation is like that between a Father-creator and the creation. Hillar mentions the father-son-grandson connection, but does not elaborate in this short summary (Hillar 2012, 184-186).

Ritter and Preller use the "division" of the Second god into a Second and a Third god as a justification for their theory that the Second god is the Good cosmic soul, and the Third is the Evil cosmic soul (Ritter, Preller 1898, 516 apud J. L. Langseth 2013, 108, non vidi). Langseth thinks that Numenius would be appalled by this suggestion (ibid).

O'Brien remarks that the Demiurge seems to be turned in two directions during the act of cosmogony: he contemplates the Forms and the transposes the Intelligible onto the sensible realm. A part of the problem consists in the question about why this is exactly. The Demiurge should be divided into two by the Dyad. O'Brian does not think that it is a case in which the upper or rather, the upper-tending part of the divinity, returns to contemplating the Forms, and the lower part applies itself to a constant creation of the sensible world. It is possible that the Third god is merely a lower aspect of the Second. Clearly the Demiurge creates as a result of lust, of desire, which is not particularly commendable, for this prevents him from contemplating the intelligible realm, and makes him forget his own nature. This "sinful element" can be seen as rejected by the Second God, similarly to the expulsion of Sophia from the Pleroma in the Gnostic systems. Still, O'Brian does not think that it is necessary to posit a lower aspect of the Second god - the lust of the Demiurge can be seen in a more benevolent light, as part of the natural desire to create (which can be thought of as the reason why the First god produces the Second god). It is pos- 
sible, O'Brian adds, that the First God has simply divided a preexisting entity into a Second and a Third god, who then share the function of the Demiurge. This, however, creates difficulties in the explanation of the grandfather-fatherson terminology in Proclus, and with the approach to fr. 12 (O'Brien 2015, 145).

Undoubtedly, in the hierarchy of the three gods there is certain confusion, possibly due to the scarcity of the extant sources. Still, many of the concepts by Numenius are clearly expounded and constitute a complex and challenging theological and ontological constellation. The theology in Numenius is enormously important as a separate area, for the research of the systems of the platonic tradition, and the development of the ancient concepts of the Demiurge.

\section{References:}

CARABINE, D. (1995). The Unknown God. Louvain: Peeters Press.

De VoGeL, C. J. (1964). Greek Philosophy, vol 3. Leiden: Brill.

Dillon, J. (1971). “Harpocration's ‘Commentary on Plato: Fragments of a Middle Platonic Commentary." California Studies in Classical Antiquity 4, 127, n. 4: 125-146.

Dillon, J. (1996). The Middle Platonists - 80 B.C. to A.D. 220, Ithaca: Cornell University Press.

Dillon, J. (2007). „Numenius: Some Ontological Questions.“ Bulletin of the Institute of Classical Studies, Supplement No. 94, Greek \& Roman Philosophy 100 Bc - 200 ad: Volume II, pp. 397-402.

Dillon, J. (1992). "Pleroma and Noetic Cosmos: A Comparative Study." In J. T. Wallis, J. Bregman, Eds. Neoplatonism and Gnosticism. Albany: State University of New York, pp. 99-110.

DODDS, E. R. (1960). “Numenius and Ammonius". Les Sources de Plotin. Entretiens Fondation Hardt 5, Genève: Vandoeuvres, pp. 3-32.

DÖRRIE, H. (1970). “Der König: Ein Platonisches Schlüsselwort.” Révue Internationale de Philosophie 24: 217-235.

FREDE, M. (1987). “Numenius.” ANRW 2.36.2: 1054-1055.

HILlaR, M. (2012). From Logos to Trinity - The Evolution of Religious Beliefs from Pythagoras to Tertullian. Cambridge: Cambridge University Press.

LANGSETH, J. L. (2013). Knowing God: a study of the argument of Numenius of Apameia's On the good, PhD thesis, University of Iowa.

Martano, G. (1960). Numenio d'Apameo: Un Precursore del Neo-Platonismo. Napoli: Casa editrice Armani.

MeAD, G. R. S. (1906). Corpus Hermeticum, vol. II, Theosophical Publishing Society, 1906, <http://gnosis.org/library/grs-mead/TGH-v2/th221.html> (15.05.2020). 
Merlan, P. (1962). “Drei Anmerkungen zu Numenius.” Philologus 106: 137-145.

Merlan, P. (1967). “Greek Philosophy from Plato to Plotinus." In A. H. Armstrong, Ed., The Cambridge History of Late Greek and Early Medieval Philosophy. Cambridge: Cambridge University Press, pp. 14-135.

NumÉNIUS (1973). Fragments. E. Des Places, trans.\&ed. 'Budé' édition. Paris: Belles Lettres.

NumeNIUS (2014). Numenius' fragments, draft translation, based on the 1972 'Budé' edition by E. des Places, Numénius, Fragments, Belles Lettres, Paris, G. BoysStones, trans. Durham University.

O'BriEN, C. S. (2015). The Demiurge in Ancient Thought, Cambridge: Cambridge University Press.

Philo of AleXANdria (1993). The Works of Philo, Complete and Unabridged, C. D. Yonge, trans.\&ed. Peabody: Hendrickson.

Plato (1997). Complete Works. J. M. Cooper, trans.\&ed. Indianapolis: Hackett Publishing Company.

PueCH, H-Ch. (1934). „Numénius d'Apamée et les théologies orientales au second siècle."Aiphos, 2: 745-778.

Rist, J. M. (1962). "Theos and the One in Some Texts of Plotinus." Medieval Studies, 24: 169-180.

RitTer, H, Preller, L. (1898). Historia Philosophiae Graecae, Gotha: Friedrich Andreas Perthes.

TARRANT, H. (1983). "Numenius' fr. 13 and Plato's Timaeus." Antichthon 13: 19-29.

ТодорОвСКА, М. (2018). „Одредени аспекти од онтодошките системи на Апулеј и на Нумениј." Филозофска трибина 41, бр. 22-23: 175-195.

WhitTAKer, J. (1967). “Moses Atticizing.” Phoenix, 21: 196-201.

WhitTAKer, J. (1978). "Numenius and Alcinous on the First Principle." Phoenix, Vol. 32, No. 2: 144-154. 